\title{
Financial Report for Micro, Small, and Medium Enterprise According to Financial Accounting Standards: Case Study Rafita Cake
}

\author{
Rahmad Firdaus $^{1}$, Ludovicus Sensi Wondabio ${ }^{1}$ \\ ${ }^{1}$ Faculty Economics and Business, Universitas Indonesia, Depok, 16424, Indonesia \\ *rahmad.firdaus@gmail.com
}

\begin{abstract}
The main obstacle faced by SME's is capital problem. To overcome this problem, in 2007 the President launched the Kredit Usaha Rakyat (KUR) program whose guarantee was facilitated by the government. In practice, the realization of KUR is still far from the target, the reason is the bank did not get enough information related to the condition of SME's, so the bank became very careful in distributing credit. One of the information required by the banks is the financial statements, but many SME's perpetrators have not prepared financial statements in accordance with the standards. In addition to the lack of accounting knowledge, existing standards are also considered quite complex. At the end of 2016 the Indonesian Institute of Accountants issued Financial Accounting Standards of Micro, Small and Medium Entities. This standard is very simple and easy to implement so it is expected to help the SME's perpetrators in preparing financial statements.
\end{abstract}

Keywords: Capital; Financial Accounting Standards of Micro, Small and Medium Entities; Financial Statements; Small and Medium Enterprises (SMEs).

\section{INTRODUCTION}

Micro, Small and Medium Enterprises (MSME) proved to be a major contribution to the Indonesian economy. Refer to the Ministry of Cooperatives and Small and Medium Enterprises (2005), the role of MSME in the Indonesian economic, such as: (1) as a major player in various industrial sectors, (2) SMEs as the largest employer absorbed, (3) important players in community empowerment and development (4) as a source of innovation and creator of new markets, and (5) contribute through export activities, thus contributing to the balance of payments ${ }^{1}$.

The huge potential of MSME is also not avoided from various obstacles, to overcome one of the constraints, namely capital, then in November 2007 the President launched the program of People Business Credit Program (PBCP). PBCP can be accessed by cooperatives and SMEs, especially those engaged in productive business sector. The realization of PBCP distribution in 2015 still has not reached the target, only IDR 21.4 trillion or $71.3 \%$ of the targeted IDR 30 trillion. Banks designated as credit distributors do not get sufficient information related to MSMEs conditions, so banks become very cautious in disbursing credit, this is what causes the low distribution of $\mathrm{PBCP}^{2}$. This condition occurs because MSMEs do not have reliable financial statements and in accordance with accounting standards applicable in the financial industry. With the limited understanding of accounting, the complexity of the accounting process, and the assumption that financial reporting is not an important for MSME resulted in the implementation of bookkeeping is quite complex for the perpetrators of MSME.

In order to make modern, advanced, and independent MSME, and able to access finance sources in the financial industry, the Indonesian Institute of Accountants as the standard setter prepares the Financial Accounting Standards of Micro, Small, Medium Enterprises (FAS for MSME). FAS for MSME is expected to help MSME achieve financial literacy so that MSME have the ability to optimize every opportunity available in the financial industry to maximize its performance.

\section{LITERATURE REVIEW}

Definition of financial statements is a structured presentation of the financial position and financial performance of an entity ${ }^{3}$. Meanwhile, according to Kieso, Weygandt and Warfield, financial statements are the main means to communicate financial information to outside parties. This report provides a history of the company as measured in units of currency ${ }^{4}$.

The purpose of the financial statements is to provide information related to the financial position, performance, and changes in the financial position of a company that benefit a large number of users in economic decision making ${ }^{3}$.

The International Accounting Standards Committee Foundation (IASCF) (2007) defines SMEs as an entity that lacks public accountability and makes financial statements for general purposes only for external parties. Researchers have differing opinions on the definition of micro, small and medium enterprises (SMEs) ${ }^{5}$. Some 
researchers define based on the size of their business, some use the capital asset approach, and some define it based on the ability of the workforce and the annual sales rate. Other researchers also base their opinions on the legal status and production methods of a business unit. In Indonesia, MSME groupings use net asset value and annual sales criteria.

The World Bank groups MSMEs based on the number of its employees, micro enterprises with 10 with employees; small enterprises with 30 employees; and medium enterprises with employees up to 300 people. While the countries in the European Union using labor, sales, and total balance sheet in classifying SMEs ${ }^{6}$. Countries in Europe classify MSMEs by the number of units of work in a year, annual sales, and total balance sheets ${ }^{7}$. And Asian Development Bank (ADB) in 2014 compiles the definition of MSMEs in Asia Pacific countries. Asia Pacific countries use employee, asset, turnover, capital, by sector, and legal basis in the definition of MSMEs.

In 2004 United Nations has issued Accounting and Financial Reporting Guidelines for Small and MediumSized Enterprises (SMEGA) which is a guide for MSMEs in preparing their financial statements. Then in 2009, the International Accounting Standards Board (IASB) also publishes International Financial Reporting Standards (IFRS) for SME.

In Indonesia, in 2009 the Financial Accounting Standards Board issued Financial Accounting Standards (FAS) for MSMEs, called FAS Entities without Public Accountability (EWPA) and became effective on January 1, 2011. FAS EWPA is the result of adoption from IFRS for SME's with modifications to conditions in Indonesia as well as more concise and simple than general FAS (IFRS). And in the end of 2016, Indonesian FASB authorizes FAS for Micro, Small, and Medium Entities (MSME) which is a new FAS for MSMEs with a simpler standard than FAS EWPA.

The background of the issuance of FAS MSME is because in its implementation, FAS EWPA is considered too complex while many MSME perpetrators do not have sufficient knowledge on the preparation of financial statements so that most of the perpetrators of MSMEs are not able to apply this SAK. The development of Micro Finance Institutions (MFIs) also encourages the issuance of new, simpler accounting standards, since MFIs, when viewed from their capital size, are unlikely to use FAS EWPA in preparing their financial statements. These microfinance institutions are overseen by the Financial Services Authority (FSA). Within a year, FSA requires microfinance institutions to submit periodic financial reports every four months. In addition, many researches provide recommendations for the preparation of a simpler financial accounting standard for MSMEs. The implementation of FAS EWPA in 2011 still encountered obstacles that are feared to obstruct the application of this FAS $^{8}$. The biggest obstacle is the low understanding of MSME entrepreneurs who will use this FAS ${ }^{8}$.

Under FAS for MSME, the components of the required financial statements are the Statements of Financial Position, Income Statement and Notes to Financial Statements. However, the entity is allowed to present the components of other financial statements if the information in the report adds benefits to its users. The Indonesian FASB considers similar financial accounting standards issued elsewhere, and similar accounting guidelines prepared by other international standard boards. Indonesian taxation regulations also become Indonesian FASB considerations, so it is expected that the financial statements can be the basis for the entity in carrying out its tax obligations.

\section{RESEARCH METHOD}

This study is a case study conducted in single unit of analysis, namely Rafita Cake cake shop. The data type used is primary data, which is data obtained directly from research object. Research methods used in this paper are as follows:

1. Descriptive qualitative is by describing the data or events as it is and explain the data or events with qualitative explanation sentences.

2. Field research in the form of observation and direct interview with the owner and the administration and finance of Rafita Cake.

3. Documentation study, performing historical data of the research object and see how far the running process has been well documented. The study was conducted on monthly report documents and transactional evidence during 2015 and 2016.

4. Library study, by collecting and studying various literatures such as textbooks, journals, and articles related to the preparation of financial statements on MSMEs.

5. Comparative analysis, by comparing financial statements made by the administration and finance of Rafita Cake with financial accounting standards.

Rafita Cake owner realizes the importance of financial statements, as the information contained in the financial statements can be the basis for decision making. From the financial statements can also note the performance of entities within a period.

However, the current financial statements are still very simple, only providing information on cash receipts and disbursements. The financial statements are made solely on the basis of daily sales receipts and daily 
expenditure records. From the existing financial statements, it can be seen how many monthly sales, the amount of expenses consisting of operational costs, variable costs, fixed costs, and other costs. It also records the amount of debt payments. From all the information can know the amount of profit or loss in a period.

The obstacle faced by Rafita Cake in the effort to prepare the financial statements is the lack of knowledge and information about the existence of a financial reporting standard, besides the employees who have the background of accounting education also does not exist.

\section{RESULTS AND DISCUSSION}

The Store Owner recognizes the importance of the financial statements, including providing financial information, to measure the performance and achievements of the Stores over a period, and as the main document for the requirement of funding. Based on the process of sale and purchase and the process of acceptance and expenditure of money above, coupled with existing supporting documents, the author tries to prepare the financial statements of Stores for the period of 2016 and 2015 in accordance with Financial Accounting Standards, especially financial accounting standards for Micro, And Medium (MSME). Here are some other considerations why the authors chose not to use the General financial accounting standards or financial accounting standards EWPA in preparing the store financial statements.

1. The purpose of financial reporting, the store is currently in need of funding to expand its business. The tried alternative is to find a partner from an individual and apply for a loan to the bank. One of the requested requirements is an adequate financial report. With financial accounting standards for MSME only, the Shop has been able to prepare adequate financial statements in accordance with the terms of funding.

2. The size of the business, within the scope of financial accounting standards for MSME mentioned other than those that do not have significant public accountability, the entity that can use this financial accounting standards is an entity that conforms to the criteria of MSME as stipulated in the prevailing laws and regulations in Indonesia. Based on the criteria of the law, Stores is classified into small business type.

3. Convenience, financial accounting standards for MSME is much simpler than financial accounting standards EWPA, in its application is also easier. Since this is the first time Stores want to standardize financial statements, it was decided to use financial accounting standards for MSME.

4. Human resources, the store's financial department, haven't an accounting background nor does it have a lot of information about financial statements that meet the standards. So if the Store will prepare financial statements based on financial accounting standards EWPA which is still quite complex, it will even complicate the process of preparing financial statements.

5. Business development, with daily business activities undertaken and current developments, in the medium term, then the Store will be able to growth to medium-sized enterprises in accordance with the business classification according to Law no. 20 2008. Even with medium-sized enterprises, financial accounting standards for MSME is still relevant to be used as standard in Store report preparation.

Based on the above matters, the authors decided to arrange the financial statements of the Store using financial accounting standards for MSME. The process of preparing the Store financial statements begins by identifying the list of accounts that correspond to the business processes that are run and determining the beginning balance of each list of accounts. Determining the beginning balance is the most difficult part, because there are accounts that are not properly maintained. Then collect the documents for the analysis of transactions, and then proceed with a journal entry for each transaction.

The financial statements are prepared using the Financial Accounting Standards of Micro, Small and Medium Enterprises. Financial statements are prepared on historical cost and using the accrual basis of assumptions. The currency used in the presentation of financial statements is the rupiah.

Compared to 2015, total assets in 2016 increased 25.42\%. The total asset composition in 2016 is divided into 39\% current assets and 61\% non-current assets. While in 2015 current assets $40 \%$ and non-current assets $60 \%$. Current assets increase $24.08 \%$ or 31 million due to an increase in cash \& banks, receivables and inventories that were directly proportional to the increase in sales. Non-current assets increase $26.29 \%$ or 51 million due to new fixed asset purchases to support production and sales.

The composition of liabilities and capital in 2016 is 15\% and 85\% respectively, did not change significantly from 2015. Short-term liabilities increase $18.90 \%$ or 9 million due to an increase in the number of cake production to support the needs of sales. And equity increased $26.61 \%$ or as much as 73 million which is the result of net profit of the year after deducting with personal takeover by shop owner.

Sales increase $11.57 \%$ or 138 million due to increased demand for Rafita cake products and also the opening of several new resellers. An increase in expenses of $10.44 \%$ or 112 million is directly proportional to the increase in sales, especially for production costs. Tax expense also increased by 1 million or $11.57 \%$ as sales also increased. The tax expense is calculated as $1 \%$ of the value of the sale, in accordance with Indonesian tax laws for entities whose sales in one year are less than 4.8 billion. 
Table.1. Financial Statement for Rafita Cake

Statement of Financial Position
Current Asset
Non Current Assets
Total Assets

Short Term Liability

Equity

Total Liability and Equity

\section{Income Statement}

Revenue

Operating Expenses

Profit Before Tax

Income Tax Expenses

Net Income

\begin{tabular}{|c|c|c|c|}
\hline 2016 & 2015 & Changes & $\%$ \\
\hline 159.549 .962 & 128.583 .863 & 30.966 .099 & $24,08 \%$ \\
\hline 247.055 .277 & 195.620 .833 & 51.434 .444 & $26,29 \%$ \\
\hline 406.605 .239 & 324.204 .696 & 82.400 .543 & $25,42 \%$ \\
\hline 59.558 .060 & 50.092 .800 & 9.465 .260 & $18,90 \%$ \\
\hline 347.047 .179 & 274.111.896 & 72.935.283 & $26,61 \%$ \\
\hline 406.605 .239 & 324.204 .696 & 82.400 .543 & $25,42 \%$ \\
\hline
\end{tabular}

2016

2015

Changes \%

1.329.846.031 1.191.930.000 137.916.031 11,57\%

$\begin{array}{llll}1.181 .612 .288 & 1.069 .903 .068 & 111.709 .220 & 10,44 \%\end{array}$

$\begin{array}{lllll}148.233 .743 & 122.026 .932 & 26.206 .811 & 21,48 \%\end{array}$

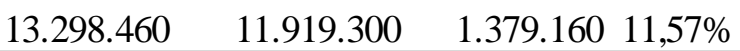

\begin{tabular}{lll}
134.935 .283 & 110.107 .632 & $24.827 .651 \quad 22,55 \%$ \\
\hline
\end{tabular}

Table.2. Financial Ratio for Rafita Cake

\begin{tabular}{|c|l|r|r|}
\hline \multicolumn{2}{|c|}{ Description } & \multicolumn{1}{c|}{$\mathbf{2 0 1 6}$} & \multicolumn{1}{c|}{$\mathbf{2 0 1 5}$} \\
\hline \multirow{4}{*}{$\begin{array}{c}\text { Operating } \\
\text { cycle }\end{array}$} & Number of days of inventory & 15,88 & 15,84 \\
\cline { 2 - 4 } & Number of days of receivables & 13,02 & 11,70 \\
\cline { 2 - 4 } & Number of days of payables & 21,35 & 22,87 \\
\cline { 2 - 4 } & Operating cycle & 28,90 & 27,54 \\
\cline { 2 - 4 } & Net operating cycle & 7,54 & 4,66 \\
\hline \multirow{4}{*}{$\begin{array}{c}\text { Liquidity } \\
\text { ratio }\end{array}$} & Current ratio & 2,68 & 2,57 \\
\cline { 2 - 4 } & Quick ratio & 2,15 & 2,00 \\
\cline { 2 - 4 } $\begin{array}{c}\text { Profitability } \\
\text { ratio }\end{array}$ & Cash ratio & 1,17 & 1,06 \\
\cline { 2 - 4 } & Oross profit margin & $41,65 \%$ & $41,61 \%$ \\
\cline { 2 - 4 } $\begin{array}{c}\text { Activity } \\
\text { ratio }\end{array}$ & Operating profit margin & $7,02 \%$ & $6,39 \%$ \\
\cline { 2 - 4 } & Inventory turnover & $10,79 \%$ & $9,76 \%$ \\
\cline { 2 - 4 } & Account receivable turnover & 22,99 & 23,05 \\
\cline { 2 - 4 } & Total assets turnover & 28,04 & 31,19 \\
\cline { 2 - 4 } & Fixed assets turnover & 3,07 & 3,48 \\
\hline \multirow{2}{*}{$\begin{array}{c}\text { Leverage } \\
\text { ratio }\end{array}$} & Debt to assets ratio & 2,39 & 3,20 \\
\cline { 2 - 4 } & Debt to equity ratio & $14,65 \%$ & $15,45 \%$ \\
\cline { 2 - 4 } & Equity multiplier & $17,16 \%$ & $18,27 \%$ \\
\hline \multirow{3}{*}{\begin{tabular}{c} 
Return ratio \\
\cline { 2 - 4 }
\end{tabular}} & Basic earning power ratio & $21,60 \%$ & $22,23 \%$ \\
\cline { 2 - 4 } & Return on assets & $33,19 \%$ & $33,96 \%$ \\
\cline { 2 - 4 } & Return on equity & $40,17 \%$ \\
\hline
\end{tabular}

So based on the above financial statements, both the financial position and the performance of the Store showed a positive change in the year 2016 compared with the previous year. And armed with these financial statements, Stores can be more confident to apply for loans to the bank in order to expand in the following years in accordance with the plans of the Store owner.

From these financial statements, the authors also perform the calculation of financial ratios to facilitate the analysis of financial position and performance. And based on these ratios assess whether the Shop is eligible to be 
given credit by banks.

In the operating cycle, the number of days of inventory has not changed; the average is still about two weeks. Number days of receivable increase, this indicates there is a delay in payment of reseller receivables. While the number of days payable decreased, it means that the Store made debt payment to the supplier faster than the previous year.

Store's liquidity ratio is very good, because the amount of cash owned is greater than the amount of debt. This indicates that there is no liquidity problem owned by the Store. Currently the payable held by the Store is only a debt purchase of production materials to suppliers.

Store's profitability ratio also shows a positive trend. Gross profit margin has not changed, but operating profit margin and net profit margin has increased quite well.

Overall activity ratio in 2016 has slightly decreased compared to the previous year. This shows the efficiency of the store is slightly down as a consequence of increased sales.

Leverage ratio in 2016 also slightly decreased compared to the previous year. This indicates an increase in the store ability in solve its obligations.

\section{CONCLUSION}

There are still many MSMEs who do not yet know that there is a standard that regulates the preparation of MSME financial statements, including Rafita Cake. This is understandable given the large number of MSME in the country, but not comparable with the socialization program conducted by the Financial Accounting Standards Board, so that the information received is also uneven. In addition, the imbalance of access to information technology in each region which is also one of the obstacles in the distribution of information related to this.

Limitations in this study are the existence of some documents that can't be traced, especially related to withdrawal of money from the accounts used for the daily operations of the store. This account is still one with the personal account of the shopkeeper. There is also a fixed asset purchase that is not known when the date of acquisition. Fixed assets in the form of buildings commonly used as cakes production sites, are not included in the financial statements because it is difficult to track and find out what the cost is.

The suggestion for further research is to elaborate deeply to determine the beginning balance if the beginning balance is not yet available. And ask the business owner to separate the personal assets with the assets of the business.

\section{REFERENCES}

[1] Ministry of Cooperatives and Small and Medium Enterprises. The Role of MSME in the Indonesian Economic, (2005).

[2] T. Baas, M. Schrooten. Relationship Banking and SMEs: A Theoretical Analysis. Small Business Economics, 27(2006) 127-137.

[3] Ikatan Akuntan Indonesia. PSAK 1: Penyajian Laporan Keuangan. Jakarta: (2017).

[4] D. E. Kieso, J. J. Weygandt, T. D. Warfield. Intermediate Accounting, 16th Edition (2016) 21-25.

[5] J. Abor, P. Quartey. Issues in SME Development in Ghana and South Africa. International Research Journal of Finance and Economics, 39(2010) 219-228.

[6] C. Roberts, S. Sian. Micro-Entity Financial Reporting: Perspectives of Preparers and Users, 33(2006) 1-44.

[7] R. Sava, B. Marza, N. Esanu. Financial Reporting for SME’s - Past and Perspectives. Procedia - Economics and Finance, 6(2013) 713718.

[8] R. Rudiantoro, S. V. Siregar. Kualitas Laporan Keuangan UMKM serta Prospek Implmentasi SAK ETAP. Jurnal Akuntansi dan Keuangan Indonesia, 9 (1)(2012. 